\title{
KEPUTUSAN SUMBER PEMBELANJAAN PADA USAHA MIKRO KECIL MENENGAH (UMKM) SWALAYAN DI DESA MULYOAGUNG KECAMATAN DAU MALANG
}

\author{
Fifi Rahmawati \\ Department of Management FEB UMM \\ Email:phiphiwhite28@gmail.com
}

\begin{abstract}
The purpose of this study was to determine the source of funds used in the micro and small businesses in the village supermarket Mulyoagung District of DAU. The method used is the method of survey, data analysis is qualitative descriptive analysis based on primary and secondary data. Based on the results of a survey conducted by the researchers of the 10 self-service according to the class of micro enterprises in the village Mulyoagung DAU Malang, there is a $100 \%$ initial planning. the source of funds used for micro and small businesses in the supermarket, the source of funds used approximately $75.5 \%$ use their own capital due, which was developed in the supermarket business is already quite big and cost quite a lot. Supermarkets that require considerable cost using capital loans at the bank around $24.5 \%$ to run a business in this way could make more developed self.
\end{abstract}

Keywords: Source of Funds, Equity, Equity Loans, UMKM

\section{PENDAHULUAN}

Sumber pendanaan atau pembelanjaan terdiri dari pinjaman atau hutang dan modal sendiri. Penggunaan dari masing-masing jenis modal mempunyai pengaruh berbeda terhadap laba bersih yang diperoleh perusahaan. Penggunaan modal dari pinjaman akan menurunkan laba bersih, sebab harus membayar bunga. Namun, besarnya bunga dimanfaatkan sebagai pengurang pajak yang harus di tanggung perusahaan. Sedangkan penggunaan modal sendiri, kompensasinya berupa pembayaran dividen yang diambilkan dari laba bersih setelah pajak (tidak mengurangi pajak). Kombinasi dari berbagai sumber dana mencerminkan struktur keuangan dan struktur modal suatu perusahaan.

Struktur modal tidak hanya penting bagi perusahaan-perusahaan besar, tetapi perusahaan dalam skala kecil atau UKM juga perlu membuat struktur modal dalam perencanaan keuangannya. Dalam penelitian ini, peneliti berfokus pada UMKM di Kota Malang.

Pertumbuhan UMKM di beberapa kota-kota besar terus menunjukkan peningkatan. Kota Malang dikenal sebagai kota pendidikan yang menjadi salah satu kota tujuan para pelajar maupun mahasiswa dari berbagai daerah, hal ini menjadi potensi besar bagi para pelaku UMKM untuk mengembangkan usahanya di kota Malang seperti swalayan yang 
merupakan sebuah toko dan menjual segala kebutuhan sehari-hari. Barang barang yang dijual di swalayan biasanya adalah barang barang kebutuhan sehari hari, seperti bahan makanan, minuman, dan barang kebutuhan seperti tissue, alat buku tulis dan lain sebagainya.

UMKM merupakan sebuah lembaga yang mampu bertahan meski dalam kondisi perekonomian negara yang tidak kondusif. UMKM bukan sebuah usaha besar namun keberadaannya menjadi sangat penting dikarenakan kinerja UMKM cenderung lebih baik dalam hal menghasilkan tenaga kerja yang produktif, mampu mencapai peningkatan produktifitasnya melalui investasi dan perubahan teknologi, dan kepemilikan keunggulan dalam hal fleksibilitas dari pada usaha besar. Sumber anggaran pada Desa Mulyoagung DAU mempunyai pengaruh yang cukup besar terhadap penambahan dan pengurangan jumlah anggaran Desa. Jika dilihat menurut tabel dibawah ini maka,terlihat adanya jumlah pendapatan asli Desa sebesar Rp446.100.050, dan Sumber pendapatan lain yang sah dan tidak mengikat sebesar Rp19.750.000, sedangkan jumlah belanja publik/belanja pembangunan sebesar Rp181.684.000, dan jumlah belanja aparatur / pegawai sebesar Rp227.638.800 dari data tersebut maka potensi yang ada di desa Mulyoagung DAU harus dapat ditingkatkan untuk memberikan pemasukan yang lebih besar terhadap anggaran Desa.

Penjualan per tahun pada Usaha Mikro Kecil Menengah (UMKM) Swalayan di Kecamatan DAU Kabupaten Malang memiliki omset penjualan yang berbeda-beda. Omset adalah total penjualan kotor yang dihitung per satuan waktu seperti harian/ bulanan/ tahunan. Omset merupakan cara singkat menyebut total penjualan, karena hanya dua suku kata omset. Secara mudah menghitung omset yakni harga jual barang dikalikan jumlah barang yang sudah terjual.

Berdasarkan latar belakang masalah dalam penelitian, maka dapat dirumuskan masalah sebagai berikut: Bagaimana keputusan sumber pembelanjaan pada Usaha Mikro Kecil Menengah (UMKM) Swalayan di Desa MulyoAgung Kecamatan DAU Malang?. Berdasarkan rumusan masalah, peneliti membatasi masalah agar tidak terjadi pelebaran pembahasan tentang Keputusan Sumber Pembelanjaan Pada Usaha Mikro Kecil Menengah (UMKM). Dalam penelitian ini akan membatasi permasalahan Keputusan Sumber Pembelanjaan Pada Usaha Mikro Kecil Menengah (UMKM).

\section{TINJAUAN PUSTAKA}

Keputusan pendanaan atau pembelanjaan Menurut Riyanto (2001:207) merupakan salah satu keputusan penting yang dihadapi oleh menajemen keuangan dalam usahanya untuk memperoleh dana guna memenuhi kebutuhan jangka pendek maupun jangka panjang perusahaan.

Sumber pendanaan atau pembelanjaan terdiri dari pinjaman atau hutang dan modal sendiri. Penggunaan dari masing-masing jenis modal mempunyai pengaruh berbeda terhadap laba bersih yang diperoleh perusahaan. Penggunaan modal dari pinjaman akan menurunkan laba 
bersih, sebab harus membayar bunga. Besarnya bunga dimanfaatkan sebagai pengurang pajak yang harus di tanggung perusahaan, sedangkan penggunaan modal sendiri yang kompensasinya berupa pembayaran dividen yang diambilkan dari laba bersih setelah pajak (tidak mengurangi pajak). Kombinasi dari berbagai sumber dana mencerminkan struktur keuangan dan struktur modal suatu perusahaan. Riyanto (2001:209) menyatakan bahwa ditinjau dari asalnya, sumber modal (pendanaan) dapat dibedakan menjadi dua, yaitu Sumber Intern adalah modal atau dana yang dibentuk atau dihasilkan sendiri didalam perusahaan seperti akumulasi penyusutan (Depresiasi) perusahaan yang berasal dari laba yang ditahan (Retained Net Profit).

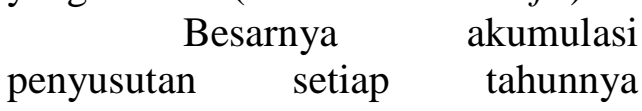
tergantung pada metode depresiasi yang digunakan oleh perusahaan yang bersangkutan. Sementara sebelum depresiasi tersebut digunakan mengganti aktiva tetap yang akan diganti, dapat digunakan untuk membelanjai perusahaan meskipun waktunya terbatas sampai saat penggantian tersebut. Kemudian selanjutnya adalah sumber ekstern yaitu dana - dana yang sumbernya dari luar perusahaan adalah dana yang berasal dari para kreditur dan pemilik, peserta atau pengambil bagian dalam perusahaan. Modal yang berasal dari para kreditur merupakan hutang bagi perusahaan yang bersangkutan dan dana ini disebut "modal asing" atau pembelanjaan asing atau pembelanjaan dengan hutang (Debt Financing), sedangkan dana yang berasal dari pemilik, peserta atau pengambil bagian didalam perusahaan adalah merupakan dana yang akan tetap ditanamkan dalam perusahaan yang bersangkutan dan dana ini dalam perusahaan tersebut disebut "modal sendiri" dimana metode pembelanjaan dana dari pemilik yang disebut pembelanjaan sendiri (Equity Financing).

Berdasarkan Undang-Undang Nomor 20 Tahun 2008 tentang Usaha Mikro, Kecil, dan Menengah (UU UMKM) Pasal 1 angka (1), (2), dan (3), Usaha Mikro adalah usaha produktif milik orang perorangan dan atau badan usaha perorangan yang memenuhi kriteria Usaha Mikro sebagaimana diatur dalam UU UMKM. Usaha Kecil adalah usaha ekonomi produktif yang berdiri sendiri, yang dilakukan oleh orang perorangan atau badan usaha yang bukan merupakan anak perusahaan atau bukan cabang perusahaan yang dimiliki, dikuasai, atau menjadi bagian baik langsung maupun tidak langsung dari usaha menengah atau usaha besar yang memenuhi kriteria Usaha Kecil sebagaimana dimaksud dalam UU UMKM.

Usaha Menengah adalah usaha ekonomi produktif yang berdiri sendiri, yang dilakukan oleh orang perseorangan atau badan usaha yang bukan merupakan anak perusahaan atau cabang perusahaan yang dimiliki, dikuasai, atau menjadi bagian baik langsung maupun tidak langsung dengan Usaha Kecil atau usaha besar dengan jumlah kekayaan bersih atau hasil penjualan tahunan sebagaimana diatur dalam UU UMKM.

UMKM adalah singkatan dari Usaha Mikro, Kecil, dan Menengah. UMKM diatur berdasarkan $U U$ Nomor 20 tahun 2008 tentang Usaha Mikro, Kecil, dan Menengah. Berikut 
kutipan dari isi UU 20/2008.

Usaha Mikro adalah usaha produktif milik orang perorangan dan atau badan usaha perorangan yang memenuhi kriteria Usaha Mikro sebagaimana diatur dalam UndangUndang ini. Usaha Kecil adalah usaha ekonomi produktif yang berdiri sendiri, yang dilakukan oleh orang perorangan atau badan usaha yang bukan merupakan anak perusahaan atau bukan cabang perusahaan yang dimiliki, dikuasai, atau menjadi bagian baik langsung maupun tidak langsung dari usaha menengah atau usaha besar yang memenuhi kriteria Usaha Kecil sebagaimana dimaksud dalam Undang-Undang ini.

Usaha Menengah adalah usaha ekonomi produktif yang berdiri sendiri, yang dilakukan oleh orang perseorangan atau badan usaha yang bukan merupakan anak perusahaan atau cabang perusahaan yang dimiliki, dikuasai, atau menjadi bagian baik langsung maupun tidak langsung dengan Usaha Kecil atau usaha besar dengan jumlah kekayaan bersih atau hasil penjualan tahunan sebagaimana diatur dalam Undang-Undang.

Kerangka pikir penelitian dibuat untuk memberikan gambaran penelitian yang akan dilakukan yakni tentang menganalisis usaha mikro kecil menengah UMKM merupakan sebuah lembaga yang mampu bertahan meski dalam kondisi perekonomian negara yang tidak kondusif. UMKM bukan sebuah usaha besar namun keberadaannya menjadi sangat penting dikarenakan kinerja UMKM cenderung lebih baik dalam hal menghasilkan tenaga kerja yang produktif, mampu mencapai peningkatan produktifitasnya melalui investasi dan perubahan teknologi, dan kepemilikan keunggulan dalam hal fleksibilitas dari pada usaha besar.

UMKM juga berhubungan dengan sumber pendanaan pada suatu usaha. Sumber pendanaan adalah sumber-sumber modal atau kebutuhan modal, baik modal investasi maupun modal kerja, dapat dicari dari berbagai sumber dana yang ada, terdiri dari modal sendiri (Intern) dan modal pinjaman atau hutang (Ekstern).

Modal yang berasal dari sumber intern adalah modal atau dana yang dibentuk atau dihasilkan sendiri didalam suatu perusahaan. Danadana yang berasal dari sumber ekstern atau luar perusahaan adalah dana yang berasal dari para kreditur dan pemilik, peserta atau pengambil bagian dalam perusahaan.

Keputusan pendanaan atau pembelanjaan (financing decision) yang menghasilkan kebijakan mengenai sumber pendanaan. Dalam kebijakan pendanaan, manajer keuangan dituntut untuk mempertimbangkan dan menganalisis kombinasi berbagai sumber dana yang ekonomis bagi perusahaan, guna membelanjai berbagai kebutuhan investasi serta kegiatan usahanya.

\section{METODE PENELITIAN}

Penelitian ini dilakukan di Swalayan yang berlokasi di Kecamatan DAU Kabupaten Malang. Jenis penelitian ini adalah deskriptif kualitatif, dimana salah satu jenis penelitian yang tujuannya untuk menyajikan gambaran lengkap mengenai seting sosial atau dimaksudkan untuk eksplorasi dan klarifikasi mengenai suatu fenomena atau kenyataan sosial, dengan jalan mendeskripsikan sejumlah variabel yang berkenaan dengan masalah dan 
unit yang diteliti antara fenomena yang diuji. Adapun dilakukan peneliti dengan mendistribusikan kuisioner terhadap responden untuk mengetahui dari mana sumber dana pada usaha mikro dan kecil pada swalayan di Kecamatan DAU Kabupaten Malang, adapun tahap-tahap dalam menganalisis data adalah melakukan interprestasi kuisioner dari responden-responden kedalam bentuk tabulasi, hasil dari tabulasi tersebut dilakukan analisis secara keseluruhan, dan menarik kesimpulan dari hasil analisis tabulasi tersebut, untuk mengetahui sumber dana yang digunakan dan hambatan akses sumber dana.

\section{HASIL PENELITIAN DAN PEMBAHASAN}

Tabel 1 menjelaskan bahwa penelitian pada populasi ini yang diambil berjumlah 15 swalayan dan untuk sampel penelitian yang termasuk dalam kriteria UMKM tersebut hanya 10 dari 15 swalayan di Kecamatan DAU Desa Mulyoagung. Jenis penelitian ini mempunyai kriteria UMKM dengan golongan usaha mikro dimana asetnya maksimal 50 juta dan omset pertahunnya maksimal 300 juta. Total tenaga kerja ada kurang dari 7 . Berikut adalah data survei swalayan. Swalayan yang tidak termasuk pada kriteria umkm ada 5 swalayan yang bukan kriteria dalam penelitian ini disebut golongan usaha kecil dimana usaha kecil adalah usaha ekonomi produktif yang berdiri sendiri, yang dilakukan oleh orang perorangan atau badan usaha yang bukan merupakan anak perusahaan atau bukan cabang perusahaan yang dimiliki, dikuasai, atau menjadi bagian baik langsung maupun tidak langsung dari usaha menengah atau usaha besar yang memenuhi kriteria Usaha Kecil. Golongan atau kriteria usaha kecil ini mempunyai target pada aset dan omset penjualan per tahunnya, yakni untuk aset $>50$ juta -500 juta dan omsetnya $>300$ juta $-2,5$ miliar.

Penelitian ini memiliki keterbatasan untuk diteliti dan untuk mempermudah penelitian ini, maka akan ditentukan sampel yang akan mewakili penelitian ini dengan teknik purposive. Modal usaha dibawah 200 Juta Rupiah diluar bangunan dan kendaraan.

Kriteria tersebut akan dapat diketahui dengan cara melakukan observasi ataupun wawancara tak terstruktur pada UMKM pada wilayah tertentu yang dilakukan oleh peneliti. Kemudian peneliti akan menyimpulkan bahwa UMKM tersebut dapat dijadikan sampel pada penelitian.

Analisis data pada penelitian ini tentang sumber pendanaan pada UMKM yang berada di Swalayan Kecamatan DAU Desa Mulyoagung dapat dilakukan dengan cara mengumpulkan hasil kuisioner secara keseluruhan dan menggunakan sampling yang digunakan menurut kriteria atau golongan usaha mikro yakni 10 UMKM (swalayan) yang telah dididstribusikan. Pemilik usaha menjadi aktor utama dalam setiap pengambilan kebijakan dan keputusan usaha yang dijalankan, begitu pula dalam hal pengelolaan aktivitas sehari-hari. Usaha yang dimiliki perorangan atau kepemilikan tunggal memiliki tanggung jawab tidak terbatas terhadap seluruh aktivitas usaha, namun terdapat keuntungan 
pada usaha yang dimiliki sendiri yaitu proses pendiriannya mudah dan tidak berbelit-belit, cocok untuk usaha kecil, tidak memerlukan biaya yang berlebihan, memiliki keleluasaan dalam hal mengambil keputusan.

Tabel 1. Data Survei 15 swalayan (UMKM di Desa Mulyoagung Kecamatan DAU Malang)

\begin{tabular}{|c|c|c|c|c|c|c|}
\hline \multirow[b]{2}{*}{ No. } & \multirow{2}{*}{$\begin{array}{c}\text { Nama } \\
\text { Swalayan }\end{array}$} & \multirow{2}{*}{$\begin{array}{l}\text { Modal } \\
\text { Awal } \\
\text { (Rp.) }\end{array}$} & \multicolumn{2}{|c|}{ Modal Usaha (\%) } & \multirow{2}{*}{$\begin{array}{c}\text { Omset } \\
\text { Penjualan } \\
\text { (Rp.) }\end{array}$} & \multirow{2}{*}{$\begin{array}{c}\text { Golongar } \\
\text { Usaha }\end{array}$} \\
\hline & & & $\begin{array}{l}\text { Modal } \\
\text { Sendiri }\end{array}$ & $\begin{array}{c}\text { Modal } \\
\text { Pinjaman }\end{array}$ & & \\
\hline 1. & Mentari & 120.000 .000 & $100 \%$ & - & 250.000 .000 & $\begin{array}{l}\text { Usaha } \\
\text { Mikro }\end{array}$ \\
\hline 2. & Sri Gading & 110.000 .000 & $70 \%$ & $30 \%$ & 200.000 .000 & $\begin{array}{l}\text { Usaha } \\
\text { Mikro }\end{array}$ \\
\hline 3. & Hidayah & 65.000 .000 & $70 \%$ & $30 \%$ & 75.000 .000 & $\begin{array}{l}\text { Usaha } \\
\text { Mikro }\end{array}$ \\
\hline 4. & $\begin{array}{l}\text { Nusa } \\
\text { Indah }\end{array}$ & 70.000 .000 & $75 \%$ & $25 \%$ & 95.000 .000 & $\begin{array}{l}\text { Usaha } \\
\text { Mikro }\end{array}$ \\
\hline 5. & Barokah & 55.000 .000 & $50 \%$ & $50 \%$ & 85.000 .000 & $\begin{array}{l}\text { Usaha } \\
\text { Mikro }\end{array}$ \\
\hline 6. & Indah & 65.000 .000 & $90 \%$ & $10 \%$ & 80.000 .000 & $\begin{array}{l}\text { Usaha } \\
\text { Mikro }\end{array}$ \\
\hline 7. & $\begin{array}{l}\text { Mulya } \\
\text { Agung }\end{array}$ & 70.000 .000 & $65 \%$ & $35 \%$ & 125.000 .000 & $\begin{array}{l}\text { Usaha } \\
\text { Mikro }\end{array}$ \\
\hline 8. & NKRI & 90.000 .000 & $95 \%$ & $5 \%$ & 85.000 .000 & $\begin{array}{l}\text { Usaha } \\
\text { Mikro }\end{array}$ \\
\hline 9. & Sederhana & 80.000 .000 & $80 \%$ & $20 \%$ & 120.000 .000 & $\begin{array}{l}\text { Usaha } \\
\text { Mikro }\end{array}$ \\
\hline 10 & Anugerah & 55.000 .000 & $60 \%$ & $40 \%$ & 80.000 .000 & $\begin{array}{l}\text { Usaha } \\
\text { Mikro }\end{array}$ \\
\hline 11 & Syariah & 250.000 .000 & $70 \%$ & $30 \%$ & 400.000 .000 & $\begin{array}{l}\text { Usaha } \\
\text { Kecil }\end{array}$ \\
\hline 12 & Lumayan & 240.000 .000 & $90 \%$ & $10 \%$ & 350.000 .000 & $\begin{array}{l}\text { Usaha } \\
\text { Kecil }\end{array}$ \\
\hline 13 & $\begin{array}{l}\text { Global } \\
\text { Mart }\end{array}$ & 300.000 .000 & $80 \%$ & $20 \%$ & 360.000 .000 & $\begin{array}{l}\text { Usaha } \\
\text { Kecil }\end{array}$ \\
\hline 14 & BSM & 350.000 .000 & $100 \%$ & - & 500.000 .000 & $\begin{array}{l}\text { Usaha } \\
\text { Kecil }\end{array}$ \\
\hline 15 & Sentosa & 220.000 .000 & $85 \%$ & $15 \%$ & 350.000 .000 & $\begin{array}{l}\text { Usaha } \\
\text { Kecil }\end{array}$ \\
\hline
\end{tabular}


Tabel 2. Data Survei 10 Swalayan Menurut Kriteria UMKM

\begin{tabular}{|c|c|c|c|c|c|c|}
\hline \multirow[b]{2}{*}{ No. } & \multirow[b]{2}{*}{$\begin{array}{c}\text { Nama } \\
\text { Swalayan }\end{array}$} & \multirow{2}{*}{$\begin{array}{l}\text { Modal } \\
\text { Awal } \\
\text { (Rp.) } \\
\end{array}$} & \multicolumn{2}{|c|}{ Modal Usaha (\%) } & \multirow{2}{*}{$\begin{array}{c}\text { Omset } \\
\text { Penjualan } \\
\text { (Rp.) }\end{array}$} & \multirow{2}{*}{$\begin{array}{c}\text { Golongan } \\
\text { Usaha }\end{array}$} \\
\hline & & & $\begin{array}{l}\text { Modal } \\
\text { Sendiri } \\
\end{array}$ & $\begin{array}{c}\text { Modal } \\
\text { Pinjaman }\end{array}$ & & \\
\hline 1. & Mentari & 120.000 .000 & $100 \%$ & - & 250.000 .000 & $\begin{array}{l}\text { Usaha } \\
\text { Mikro }\end{array}$ \\
\hline 2. & Sri Gading & 110.000 .000 & $70 \%$ & $30 \%$ & 200.000 .000 & $\begin{array}{l}\text { Usaha } \\
\text { Mikro }\end{array}$ \\
\hline 3. & Hidayah & 65.000 .000 & $70 \%$ & $30 \%$ & 75.000 .000 & $\begin{array}{l}\text { Usaha } \\
\text { Mikro }\end{array}$ \\
\hline 4. & Nusa Indah & 70.000 .000 & $75 \%$ & $25 \%$ & 95.000 .000 & $\begin{array}{l}\text { Usaha } \\
\text { Mikro }\end{array}$ \\
\hline 5. & Barokah & 55.000 .000 & $50 \%$ & $50 \%$ & 85.000 .000 & $\begin{array}{l}\text { Usaha } \\
\text { Mikro }\end{array}$ \\
\hline 6. & Indah & 65.000 .000 & $90 \%$ & $10 \%$ & 80.000 .000 & $\begin{array}{l}\text { Usaha } \\
\text { Mikro }\end{array}$ \\
\hline 7. & $\begin{array}{l}\text { Mulya } \\
\text { Agung }\end{array}$ & 70.000 .000 & $65 \%$ & $35 \%$ & 125.000 .000 & $\begin{array}{l}\text { Usaha } \\
\text { Mikro }\end{array}$ \\
\hline 8. & NKRI & 90.000 .000 & $95 \%$ & $5 \%$ & 85.000 .000 & $\begin{array}{l}\text { Usaha } \\
\text { Mikro }\end{array}$ \\
\hline 9. & Sederhana & 80.000 .000 & $80 \%$ & $20 \%$ & 120.000 .000 & $\begin{array}{l}\text { Usaha } \\
\text { Mikro }\end{array}$ \\
\hline 10 & Anugerah & 55.000 .000 & $60 \%$ & $40 \%$ & 80.000 .000 & $\begin{array}{l}\text { Usaha } \\
\text { Mikro }\end{array}$ \\
\hline & Jumlah & & $75,5 \%$ & $24,5 \%$ & & \\
\hline
\end{tabular}

Sajian hasil analisis data dapat dilihat pada tabulasi 1.2 kemudian dari hasil kuisioner yang telah diketahui jawabannya atau telah diisi oleh responden maka dapat dilakukan interpretasi kedalam bentuk tabulasi. Langkah selanjutnya adalah dari hasil tabulasi yang telah dibuat, maka dapat dilakukan analisis tabulasi dan kemudian dari hasil analisis tabulasi dapat ditarik kesimpulan secara keseluruhan untuk dapat mendeskripsikan keputusan sumber dana yang termasuk kriteria dalam golongan usaha mikro pada umkm. Modal usaha yang diperoleh oleh modal sendiri dan modal pinjaman itu sangat penting dalam mencapai suatu usahanya, tetapi usaha yang sangat membantu dalam kehidupannya sehingga mempunyai tabungan yang cukup untuk keperluan sehari - hari maupun untuk keperluan lainnya. Berguna terhadap jangka panjang untuk kedepannya. Adapun sumber dana dari pemilik pribadi tersebut berasal dari beberapa sumber dana seperti yang tertera pada tabel 3 .

Dilihat dari tabel 3 bahwa swalayan yang menggunakan modal sendiri hanya $10 \%$ dan $90 \%$ kebanyakan meminjam dan menggunakan modal sendiri untuk mendirikan usaha swalayan tersebut. Presentase dari swalayan tersebut yang menggunakan modal sendiri yakni sekitar $75,5 \%$ dan modal pinjaman sekitar 24,5\%. Hal ini sudah jelas bahwa masyarakat yang berada di Desa MulyoAgung Kecamatan 
DAU untuk mengembangkan usahanya tersebut dengan meminjam pinjaman terhadap pihak bank.

Tabel 3. Sumber Dana Swalayan

\begin{tabular}{|c|c|c|c|}
\hline \multirow{3}{*}{ No } & \multirow{3}{*}{ Swalayan } & \multicolumn{2}{|c|}{ Sumber Dana } \\
\hline & & Modal & Modal \\
\hline & & Sendiri & Pinjaman \\
\hline 1. & Mentari & $\checkmark$ & 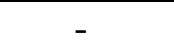 \\
\hline 2. & Sri Gading & $\checkmark$ & $\checkmark$ \\
\hline 3. & Hidayah & $\checkmark$ & $\checkmark$ \\
\hline 4 & Nusa & $\checkmark$ & $\checkmark$ \\
\hline & Indah & & \\
\hline 5. & Barokah & $\checkmark$ & $\checkmark$ \\
\hline 6. & Indah & $\checkmark$ & $\checkmark$ \\
\hline 7. & Mulya & $\checkmark$ & $\checkmark$ \\
\hline & Agung & & \\
\hline 8. & NKRI & $\checkmark$ & $\checkmark$ \\
\hline 9. & Sederhana & $\checkmark$ & $\checkmark$ \\
\hline 10. & Anugerah & $\checkmark$ & $\checkmark$ \\
\hline
\end{tabular}

\section{SIMPULAN}

Sumber dana di Desa Mulyoagung DAU berdasarkan hasil survei 10 swalayan menyatakan bahwa sumber dana yang digunakan untuk usaha mikro dan kecil pada swalayan, sumber dana yang digunakan sekitar $\quad 75,5 \%$ menggunakan modal sendiri dikarenakan, usaha yang dikembangkan pada swalayan ini sudah cukup besar dan membutuhkan biaya yang lumayan banyak. Swalayan yang membutuhkan biaya yang cukup besar ini menggunakan modal pinjaman pada pihak bank sekitar $24,5 \%$ sehingga menjalankan usaha dengan cara seperti ini bisa membuat swalayan lebih berkembang.

Semangat dan tekat para usaha swalayan ini cukup mengerti pengetahuan dalam melakukan akses sumber dana dari luar, Kriteria yang dimaksudkan ke dalam golongan usaha mikro tersebut ada 10 swalayan dimana swalayan tersebut memperoleh total aset atau modal usaha dibawah 200 juta rupiah diluar bangunan dan kendaraan, total tenaga kerja kurang dari 7 orang, omset dibawah 300 juta/ tahun dari kriteria usaha mikro yang dimaksudkan. Hal ini bisa menimbulkan kerugian atau keuntungan tetapi pada swalayan yang sudah diteliti memperoleh keuntungan setiap tahunnya.

\section{DAFTAR PUSTAKA}

Anwar Sanusi. (2011). Metodologi Penelitian Bisnis. Jilid 1. Jakarta: Salemba Empat.

Bambang Riyanto. (2001). DasarDasar Pembelanjaan Perusahaan. Yogyakarta: BPFE.

Brigham, Eugene F. dan Houston, Joel F. (2011). Manajemen Keuangan. Edisi Sebelas. Jakarta: Salemba Empat.

Linda, (2012). Analisis Dampak Kredit Mikro Terhadap Perkembangan Usaha Mikro from.

http://abstraksiekonomiblogsp ot.com/2013/12/pengertianumkm-usaha-mikro-kecildan.html

Nazir, Moh. Ph. D (2011). Metode Penelitian, Cetakan Ketujuh. Bogor: Penerbit Ghalia Indonesia.

Nurul, Amri. (2013). Pasal - Pasal pada Matriks Draf RUU Perdagangan From. http://www.google.co.id/url?s $a=t \& r c t=j \& q=\& \operatorname{esr} c=s \& s o u$ $r c e=w e b \& c d=10 \& c a d=r j a \&$ uact $=8 \& v e d=0 C F k Q F j A J \& u$ $r l$ 
Pemerintah Kabupaten Malang semarang. $\quad$ From. Kecamatan DAU, http://www.malang.malangka b.go.id

http://eprints.undip.ac.id/356 54/1/Skripsi_MAULIDA.pdf

Rika, Maulida. (2013). faktor-faktor yang mempengaruhi pendanaan modal dan peluang penggunaan dana external usaha mikro kecil dan menengah di kota Yuniar, Wahyuni. (2014). Keputusan Pembelanjaan Pada Usaha Mikro dan Kecil Pada Sektor Makanan dan Minuman di Desa Mulyoagung DAU Malang. 